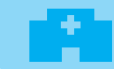

\title{
亀田総合病院 リハビリテーション科
}

\section{宮越浩一 \\ 亀田総合病院リハビリテーション科}

亀田総合病院は太平洋を望む千葉県鴨川市に昭 和 23 （1948）年に設立され，電子カルテ, ISO9001 の認証などを医療機関としていち早く導入．充実 した設備と風光明媚な環境，そして何よりも質の 高い医療を提供することで，日本全国から多数の 患者さんが集まります。

宮越浩一部長の専門分野は, がん, 脊髄損傷, 関節リウマチ，脳卒中，小児のリハビリテーション で, 急性期の高度医療を提供する「亀田総合病院」, 回復期を担う「亀田リハビリテーション病院」, 外 来専門の「亀田クリニック」の 3 つの医療機関での リハビリテーション医療を管理しています。「手術 は年間 1 万件以上で 34 の診療科があるため, 外傷 や脳血管障害の後遺症だけでなく，さまざまな疾 患の患者さんを急性期・回復期・生活期まで診療 できるのが特色です。他科医師のリハビリテー ション医療に対する理解は良好で，早期から，多く の患者さんの依頼を受けています」，取材にうか がった日の宮越先生のスケジュールは，午前中は 総合病院内で神経内科回診，䁩下回診，午後はリ ハビリテーション病院回診, 夕方から総合病院に
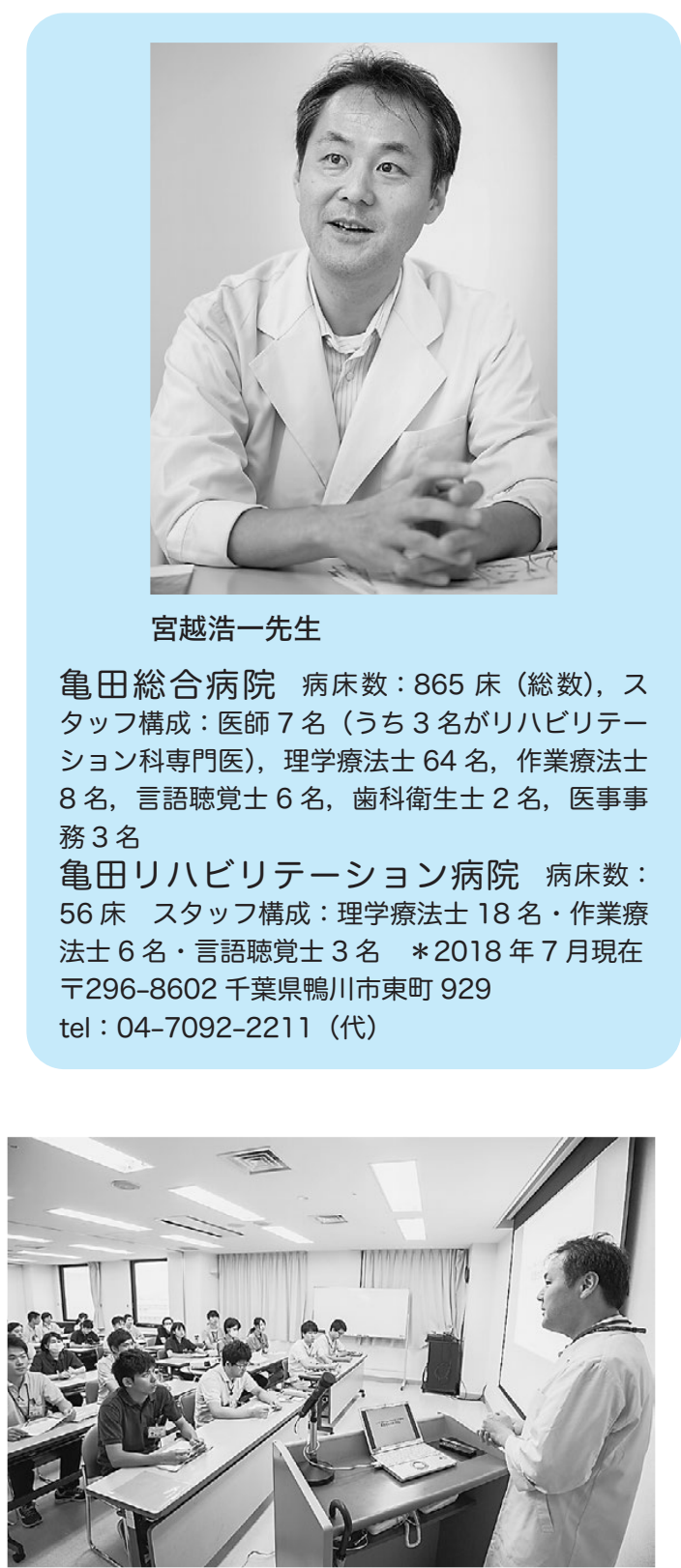

世界的建築家・安藤忠雄氏の設計した亀田リハビリ テーション病院。中庭を囲むように病室が設置さ 亀田総合病院で療法士向け勉強会の講師を務める 宮越先生. 


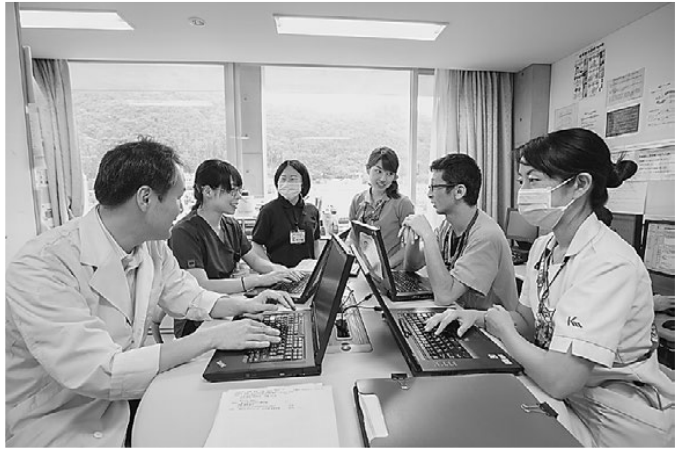

スタッフとの情報共有は顔の見えるコミュニケー ションが基本.

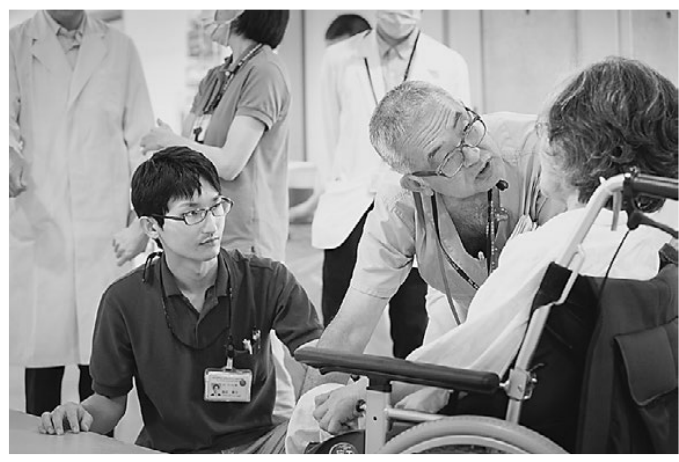

亀田リハビリテーション病院井合茂夫院長の患者 さんへの真剣なまなざしが何よりの教育になる.

㞍り療法士向け勉強会の講師を務めるなど大忙し でしたが，「療法士教育に力を入れており，教育も マニュアル化しているため, 能力のムラが少なく, 安心して業務分担をすることができます。それが ストレスのないコミュニケーションの秘訣です. ISO, JCI などの外部審査を早くから導入し, 医療 品質の管理と継続的改善を続けてきたことも効を 奏しています」と話されます.

印象的だったのは亀田リハビリテーション病院 で，世界的建築家の安藤忠雄氏の設計で, 円形の 3 階建て, コンクリート打ちっ放しで，真ん中に木 漏れ日が入る中庭があり, 広々とした病室を一歩 出るとすぐにリハビリテーションができるように工 夫されています。「ここでは『リハビリテーション 室に行く』という概念がなく, 生活の場がリハビリ テーションになっています。回診中も『ちょっと廊 下に出て歩いてみましょうか』などと患者さんを促

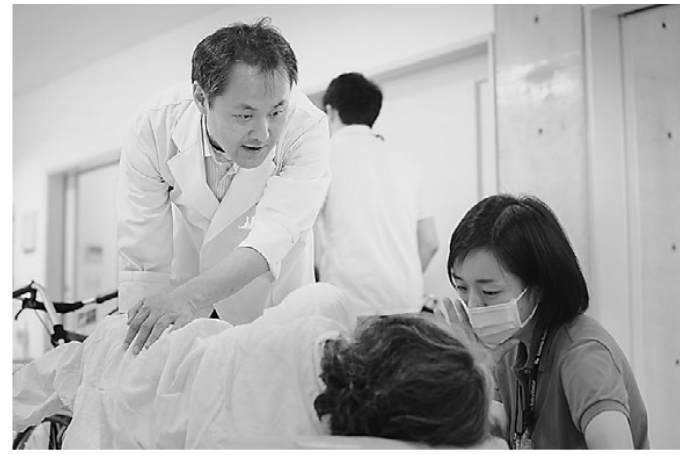

病室を出ればそこがリハビリテーション室. だから 回診時もしっかりと患者さんの動きを診察できる.

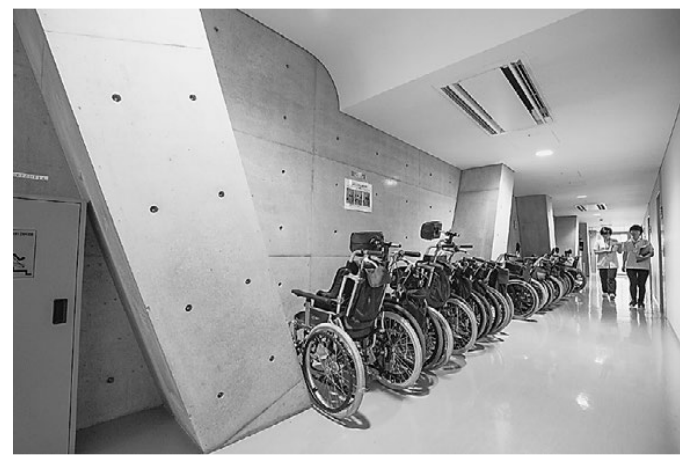

病院の内装としては珍しいコンクリート打ちっ放し だが重厚さと安定感がある.

して体の動きを診ることができます」という説明ど おり, 病室を出て歩いたり, 広い空から海を眺める 患者さんがたくさんいました.

「リハビリテーション科医の教育目標として, 臨 床・研究のみでなく, コメディカルスタッフの教育 者, 組織の管理者（診療品質管理・経営）としての 能力も身につけてもらうことをめざしています。専 攻医の QOL を重視し，ストレスのない研修をする 中で網羅的にリハビリテーション医療を経験し, バ ランスのとれた専門医を養成するように心がけて います」と話す宮越先生の言葉どおり, 恵まれた自 然環境, 充実した施設, 優秀でチームワークのよい スタッフ，ストレスなく働けるように配慮された管 理体制など，患者さんのみならず，医療スタッフに とっても理想の病院であることを心がけていること がよく理解できました。

（文責：広報委員会） 